\title{
MIR29B1 Gene
}

National Cancer Institute

\section{Source}

National Cancer Institute. MIR29B1 Gene. NCI Thesaurus. Code C80720.

This gene is involved in the regulation of gene expression and plays a role in the development of carcinoma of the lung, cholang iocarcinoma, chronic lymphocytic leukemia, acute myeloid leukemia, Alzheimer's disease and Type II diabetes. 